SJîñn Jurnal

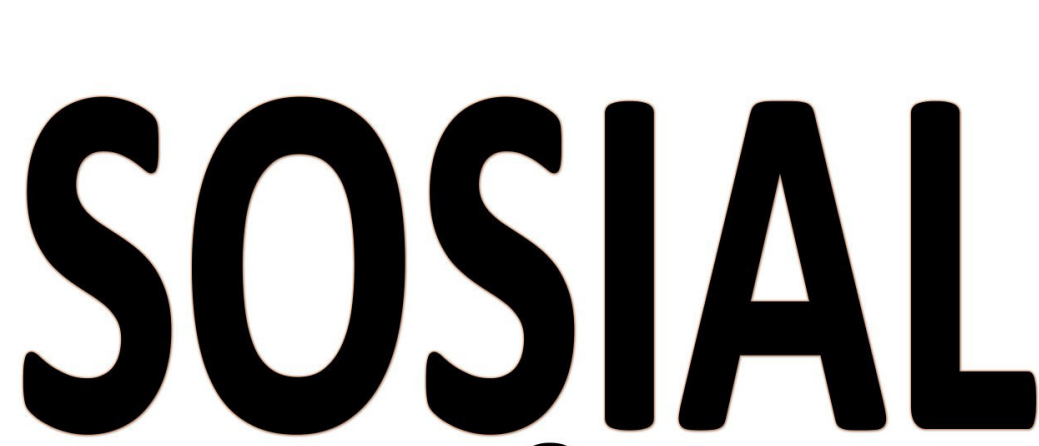

P-ISSN: 2356-1459 E-ISSN: 2654-9050 Vol. 7 No. 5 (2020)
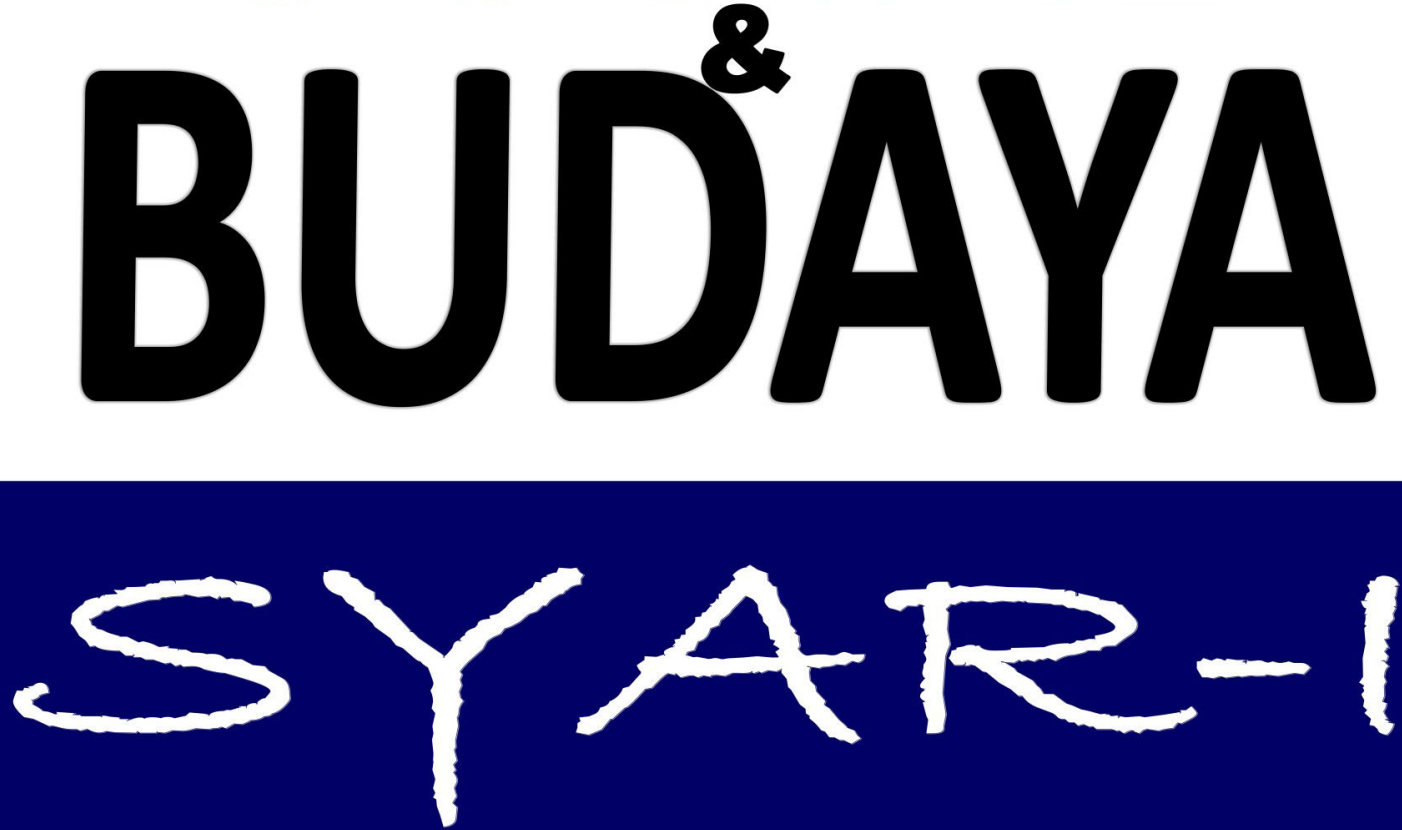

Dampak Covid-19 pada Pendidikan di Indonesia: Sekolah, Keterampilan, dan Proses Pembelajaran Rizqon Halal Syah Aji

Peran Preventif Pemimpin Dalam Pencegahan Penyebaran COVID-19; Strategi Syaykh Al-Zaytun Di Ma'had Al-Zaytun dan Kontribusinya Terhadap Masyarakat Sekitar Imam Prawoto, Siti Ngainnur Rohmah, Fitri Rachmiati Sunarya

Dari Jabariyah, ke Qadariyah, hingga Islam Progresif: Respons Muslim atas Pandemi COVID-19 di Indonesia Nur Hidayah

Transparansi Kebijakan Publik Sebagai Strategi Nasional Dalam Menanggulangi Pandemi Covid-19 Afni Regita Cahyani Muis

Peran Majelis Ulama Indonesia Dalam Mitigasi Pandemi Covid-19;

(Tinjauan Tindakan Sosial dan Dominasi Kekuasaan Max Weber)

Muhamad Agus Mushodiq, Ali Imron

Optimalisasi Upaya Pemerintah Dalam Mengatasi Pandemi Covid 19 Sebagai Bentuk Pemenuhan Hak Warga Negara

Bima Jati, Gilang Rizki Aji Putra

Pandangan Keagamaan Majelis Ulama Indonesia Kabupaten Bogor Terkait Kewajlban Menjaga Diri, Pelaksanaan Shalat Jumat dan Pengurusan Mayit Dalam Situasi Darurat Penyebaran Covid-19 Ahmad Mukri Aji 


\title{
Dampak Covid-19 pada Pendidikan di Indonesia: Sekolah, Keterampilan, dan Proses Pembelajaran
}

\author{
Rizqon Halal Syah Aji ${ }^{1}$ \\ Sekolah Ilmu Ekonomi Universitas Kebangsaan Malaysia \\ doi $\underline{10.15408 / \text { sjsbs.v7i5.15314 }}$
}

\begin{abstract}
The temporary closure of all educational institutions as an effort to prevent the spread of an outbreak of Covid-19 worldwide has an impact on millions of students, including in Indonesia. Disturbances in the teaching and learning process directly between teacher and students as well as the termination of the assessment of learning have an impact on the psychological of students, causing a decrease in the quality of skills. This burden is the responsibility of all elements of education, in particular the government, in facilitating the continuity of schools for all stakeholders in education to conduct distance education. How should Indonesia plan, prepare for and overcome co-recovery 19, to reduce the loss of education in the future.
\end{abstract}

Keywords: Covid-19, School, Stakeholders, Indonesia

\begin{abstract}
Abstrak
Penutupan sementara lembaga pendidikan sebagai upaya menahan penyebaran pendemi covid-19 di seluruh dunia berdampak pada jutaan pelajar, tidak kecuali di Indonesia. Gangguan dalam proses belajar langsung antara siswa dan guru dan pembatalan penilaian belajar berdampak pada psikologis anak didik dan menurunnya kualitas keterampilan murid. Beban itu merupakan tanggung jawab semua elemen pendidikan khususnya negara dalam memfasilitasi kelangsungan sekolah bagi semua steakholders pendidikan guna melakukan pembelajaran jarak jauh. Bagaimana mestinya Indonesia merencanakan, mempersiapkan, dan mengatasi pemulihan covid 19, untuk menekan kerugian dunia pendidikan di masa mendatang.
\end{abstract}

Kata Kunci: Covid-19, Sekolah, Steakhorders Pendidikan, Indonesia

*Diterima: 18 April 2020, Revisi: 21 April 2020, Diterbitkan 17 Mei 2020.

1 Rizqon Halal Syah Aji adalah Kandidat Ph.D pada Sekolah Ilmu Ekonomi Universitas Kebangsaan Malaysia. 


\section{Prolog}

Pandemi COVID-19 merupakan musibah yang memilukan seluruh penduduk bumi. Seluruh segmen kehidupan manusia di bumi terganggu, tanpa kecuali pendidikan. Banyak negara memutuskan menutup sekolah, perguruan tinggi maupun universitas, termasuk Indonesia. Krisis benar-benar datang tiba-tiba, pemerintah di belahan bumi manapun termasuk Indonesia harus mengambil keputusan yang pahit menutup sekolah untuk mengurangi kontak orang-orang secara masif dan untuk menyelamatkan hidup atau tetap harus membuka sekolah dalam rangka survive para pekerja dalam menjaga keberlangsungan ekonomi. Ada dua dampak bagi keberlangsungan pendidikan yang disebabkan oleh pandemi Covid-19. Pertama adalah dampak jangka pendek, yang dirasakan oleh banyak keluarga di Indonesia baik di kota maupun di desa. Di Indonesia banyak keluarga yang kurang familier melakukan sekolah di rumah. Bersekolah di rumah bagi keluarga Indonesia adalah kejutan besar khususnya bagi produktivitas orang tua yang biasanya sibuk dengan pekerjaannya di luar rumah. Demikian juga dengan problem psikologis anak-anak peserta didik yang terbiasa belajar bertatap muka langsung dengan guru-guru mereka. Seluruh elemen pendidikan secara kehidupan sosial "terpapar" sakit karena covid-19. Pelaksanaan pengajaran berlangsung dengan cara online. Proses ini berjalan pada skala yang belum pernah terukur dan teruji sebab belum pernah terjadi sebelumnya. Tak Pelak di desadesa terpencil yang berpenduduk usia sekolah sangat padat menjadi serba kebingungan, sebab infrastruktur informasi teknologi sangat terbatas. Penilaian siswa bergerak online dan banyak trial and error dengan sistem yang tidak ada kepastian, malah banyak penilaian yang banyak dibatalkan. Kedua adalah dampak jangka panjang. Banyak kelompok masyarakat di Indonesia yang akan terpapar dampak jangka panjang dari covid-19 ini. Dampak pendidikan dari sisi waktu jangka panjang adalah aspek keadilan dan peningkatan ketidaksetaraan antar kelompok masyarakat dan antardaerah di Indonesia.

\section{Dampak Covid-19 pada Proses Belajar di Sekolah}

Proses pembelajaran di sekolah merupakan alat kebijakan publik terbaik sebagai upaya peningkatan pengetahuan dan skill. ${ }^{2}$ Selain itu banyak siswa menganggap bahwa sekolah adalah kegiatan yang sangat menyenangkan, mereka bisa berinteraksi satu sama lain. Sekolah dapat meningkatkan keterampilan sosial dan kesadaran kelas sosial siswa. Sekolah secara keseluruhan adalah media interaksi antar siswa dan guru untuk meningkatkan kemampuan integensi, skill dan rasa kasih sayang diantara mereka. Tetapi sekarang kegiatan yang bernama sekolah berhenti dengan tiba-tiba karena gangguan Covid-19. Sejauh mana dampaknya bagi proses Belajar di sekolah? Khusus untuk Indonesia banyak bukti ketika sekolah sangat mempengaruhi produktivitas dan pertumbuhan ekonomi. ${ }^{3}$

${ }^{2}$ Caroline Hodges Persell, 1979, Educations and Inequality, The Roots and Results of Strattification in America's Schools, United States of America: The Free Press.

${ }^{3}$ Baharin, R., Halal, R., dll, 2020, Impact of Human Resource Investment on Labor Productivity in Indonesia, Iranian Journal of Management Studies, 13(1), hal. 139-164. 
Pada sebuah artikel yang ditulis oleh Carlsson menjelaskan dimana para remaja di Swedia memiliki jumlah hari yang berbeda untuk mempersiapkan diri menghadapi test penting. Perbedaan-perbedaan ini bersifat acak kondisional yang penulis coba mengasumsikan kondisi yang sama di Indonesia. ${ }^{4}$ Para remaja di Swedia itu menambah belajar selama sepuluh hari sekolah dan hasil yang mereka dapatkan adalah meningkatkan skor pada tes pengetahuan mereka. Begitu juga ketika kita merujuk Jonsson, bahwa menghadiri sekolah akan meningkatkan kapasitas memori murid. ${ }^{5}$ Merujuk Carlsson jika pada tes penggunaan pengetahuan dan diasumsikan setiap kehilangan tidak bersekolah selama 10 hari adalah 1 persen dari standar deviasi maka siswa sekolah maka dalam 12 minggu atau 60 hari sekolah mereka akan kehilangan 6\% dari setandar deviasi. ${ }^{6}$ Kondisi ini bukan masalah sepele. Siswa akan terganggu pengetahuan untuk masa datang dengan maslah pengetahuan yang lebih kompleks.

Hal serupa didukung oleh Lavy, yang merumuskan dampak pada pembelajaran karena perbedaan waktu pengajaran di seluruh negara di dunia. ${ }^{7}$ Ia menstimulasikan bahwa total jam mengajar mingguan dalam matematika, bahasa dan sains adalah 55\% lebih tinggi di Denmark daripada di Austria. Perbedaan ini penting sebab perbedaan signifikan dalam hasil skor test sekitar $6 \%$ dari standar deviasi seperti disebutkan di atas. Sehingga jelas berapa pun deviasi yang diterima oleh pelajar Indonesia karena kehilangan waktu belajar di sekolah jelas berakhir pada kerugian siswa akan tergerusnya pengetahuan mereka.

Kesamaan situasi Indonesia dengan negara-negara lain di belahan dunia mesti segera diatasi dengan seksama. Dalam keadaan normal saja banyak ketimpangan yang terjadi antardaerah. Kementerian Pendidikan di bawah kepemimpinan Menteri Nadiem Makarim, mendengungkan semangat peningkatan produktivitas bagi siswa untuk mengangkat peluang kerja ketika menjadi lulusan sebuah sekolah. Namun dengan hadirnya wabah Covid-19 yang sangat mendadak, maka dunia pendidikan Indonesia perlu mengikuti alur yang sekiranya dapat menolong kondisi sekolah dalam keadaan darurat. Sekolah perlu memaksakan diri menggunakan media daring. Namun penggunaan teknologi bukan tidak ada masalah, banyak varians masalah yang menghambat terlaksananya efektivitas pembelajaran dengan metode daring diantaranya adalah:

1. Keterbatasan Penguasaan Teknologi Informasi oleh Guru dan Siswa

Kondisi guru di Indonesia tidak seluruhnya paham penggunaan teknologi, ini bisa dilihat dari guru-guru yang lahir tahun sebelum 1980-an. Kendala teknologi informasi membatasi mereka dalam menggunakan media daring. Begitu juga

${ }^{4}$ Carlsson, M, G B Dahl, B Ockert and D Rooth, 2015, The Effect of Schooling on Cognitive Skills, Review of Economics and Statistics 97(3), hal. 533-547.

${ }^{5}$ Jonsson, B., Waling, M., Olafsdottir, A. S., Lagström, H., Wergedahl, H., Olsson, C., ... Hörnell, A., 2017, The effect of schooling on basic cognition in selected nordic countries, Europe's Journal of Psychology, 13(4), hal. 645-666. https://doi.org/10.5964/ejop.v13i4.1339

${ }^{6}$ Carlson, 2015, Ibid.

7 Lavy, V, 2015, Do Differences in Schools, Instrution Time Explain International Achievement Gaps? Evidence from Developed and Developing Countries, Economics Journal 125. 
dengan siswa yang kondisinya hampir sama dengan guru-guru yang dimaksud dengan pemahaman penggunaan teknologi.

2. Sarana dan Prasarana yang Kurang Memadai

Perangkat pendukung teknologi jelas mahal. Banyak di daerah Indonesia yang guru pun masih dalam kondisi ekonominya yang menghawatirkan. Kesejahteraan guru maupun murid yang membatasi mereka dari serba terbatas dalam menikmati sarana dan prasarana teknologi informasi yang sangat diperlukan dengan musibah Covid-19 ini.

3. Akses Internet yang terbatas

Jaringan internet yang benar-benar masih belum merata di pelosok negeri. Tidak semua lembaga pendidikan baik Sekolah dasar maupun sekolah menengah dapat menikmati internet. Jika ada pun jaringan internet kondisinya masih belum mampu mengkover media daring.

\section{Kurang siapnya penyediaan Anggaran}

Biaya juga sesuatu yang menghambat karena, aspek kesejahteraan guru dan murid masih jauh dari harapan. Ketika mereka menggunakan kuota internet untuk memenuhi kebutuhan media daring, maka jelas mereka tidak sanggup membayarnya. Ada dilema dalam pemanfaatan media daring, ketika menteri pendidikan memberikan semangat produktivitas harus melaju, namun disisi lain kecakapan dan kemampuan finansial guru dan siswa belum melaju ke arah yang sama. Negara pun belum hadir secara menyeluruh dalam memfasilitasi kebutuhan biaya yang dimaksud.

\section{Kerugian Siswa pada Proses Penilaian}

Ada kerugian mendasar bagi murid ketika terjadi penutupan sekolah ataupun kampus. Banyak ujian yang mestinya dilakukan oleh murid pada kondisi normal, sekarang dengan mendadak karena dampak covid-19, maka ujian dibatalkan ataupun di tunda. Penilaian internal bagi sekolah barangkali dianggap kurang urgent tetapi bagi keluarga murid informasi penilaian sangat penting. Ada yang menganggap hilangnya informasi penilaian murid sangatlah berarti bagi keberlangsungan masa depan murid. Misalkan saja target-target skill maupun keahlian tertentu murid yang mestinya tahun ini mendapatkan penilaian sehingga berdampak treatment untuk tahun yang akan datang, maka pupus sudah bagi murid yang telah mampu menguasai banyak keterampilan di tahun ini tetapi tidak memperoleh penilaian yang semestinya.

Kasus lain untuk mahasiswa di perguruan tinggi. Banyak perguruan tinggi di luar negeri mengganti ujian tradisional dengan alat bantu online. Ini adalah kondisi baru untuk dosen dan mahasiswa. Penilaian bagi mahasiswa bisa saja memiliki kesalahan pengukuran, tidak seperti pengukuran seperti biasa dilakukan. Penelitian di negaranegara Eropa bahwa pengusaha menggunakan penilaian yang berbeda yaitu dengan cara kredensial pendidikan seperti halnya klasifikasi gelar dan rata-rata nilai untuk 
menyeleksi pelamar dari kalangan alumni perguruan tinggi. ${ }^{8}$ Sehingga mempengaruhi bagaimana pelamar baru dari alumni perguruan tinggi dapat kecocokan di pasar kerja dan diterima sesuai dengan upah yang diharapkan. Begitu juga di Indonesia belum ada satu perusahaan yang mengumumkan bagaimana lulusan baru universitas dapat mengikuti seleksi di pasar kerja. Namun demikian pemerintah Indonesia menawarkan kartu pra kerja untuk melatih kembali kemahiran lulusan perguruan tinggi dalam mempersiapkan lulusan universitas untuk bekerja di masa datang pasca Covid-19.

\section{Dampak pada Lulusan Sekolah}

Lulusan universitas ataupun pendidikan menengah yang mencari pekerjaan tahun ini mengalami gangguan yang hebat karena pandemi Covid-19. Para mahasiswa maupun siswa yang tahun ini lulus mengalami gangguan pengajaran di bagian akhir studi mereka. Dampak langsung yang dialami oleh mereka adalah gangguan utama dalam penilaian akhir yang mestinya mereka dapatkan. Namun dengan kondisi apapun mereka tetap lulus dalam kondisi resesi global yang memilukan ini. Kondisi pasar kerja yang cenderung sulit merupakan kendala baru bagi lulusan. Persaingan dipasar kerja sangat "gaduh" dan berhimpit dengan para pekerja yang juga sudah mengalami Putus Hubungan Kerja (PHK) dari perusahaan dimana mereka bekerja. Adapun jika mereka sebagai lulusan baru Universitas maka mereka mau tidak mau akan menerima upah lebih rendah dan mereka akan mempunyai efek dalam persaingan karier (Bobonis \& Morrow, 2014). ${ }^{9}$ Lulusan universitas yang awalnya memprediksi dirinya akan mendapatkan pekerjaan dan upah yang memadai akan tetapi kenyataan di Indonesia disebabkan karena covid-19 mengakibatkan mereka harus berpikir ulang tentang pendidikan yang ditempuh dan mendapatkan upah yang diharapkan.

\section{Langkah Strategis dan Solusi bagi dunia Pendidikan Indonesia}

Dalam penanganan dampak Covid-19 pada dunia pendidikan, seluruh steakholders harus bahu membahu berbuat. Kondisi ini tidak boleh terlepas pandang dari kebijakan pemerintah dan pelaksanaannya operasionalisasi di lapangan. Adapun halhal yang wajib dilakukan oleh semua steakholders pendidikan adalah;

\section{Pemerintah}

Peran pemerintah sangat penting dan fundamental. Alokasi anggaran yang sudah diputuskan oleh Instruksi Presiden Nomor 4 tahun 2020 tentang refocussing kegiatan, relokasi anggaran, serta pengadaan barang dan jasa dalam rangka percepatan penanganan Covid-19 harus segera dilaksanakan.

2. Orang Tua

${ }^{8}$ Piopiunik, M, G Schwerdt, L Simon and L Woessman, 2020, Skill, signals and employability: An experimental investigation. Europan Economic Review 123: 103374

9 Bobonis, G. J., \& Morrow, P. M., 2014, Labor coercion and the accumulation of human capital, Journal of Development Economics, 108, hal. 32-53. https://doi.org/10.1016/j.jdeveco.2014.01.004 
Orang tua sebagai pendidik utama di rumah tangga harus menjalankan fungsinya. Meskipun demikian tetap saja bantuan guru di sekolah perlu hadir door to door disemua peserta didik. Ini harus membuka cakrawala dan tanggungjwab orang tua bahwa pendidikan anaknya harus dikembalikan pada effort orang tua dalam mendidikan mental, sikap dan pengetahuan anakanaknya.

\section{Guru}

Langkah pembelajaran daring harus seefektif mungkin. Guru bukan membebani murid dalam tugas-tugas yang dihantarkan dalam belajar di rumah. Jika perlu guru hadir secara gagasan dalam door to door peserta didik. Guru bukan hanya memposisikan sebagai pentransfer ilmu, tetapi tetap saja mengutamakan ing ngarso sung tulada, ing madya mangun karsa, tut wuri handayani.

4. Sekolah

Sekolah sebagai lembaga penyelenggara pendidikan harus bersiaga memfasilitasi perubahan apapun menyangkut pendidikan siswanya. Pendidikan tingkah laku harus menjadi pijakan kuat ditengah perkembangan teknologi dan arus percepatan informasi. Program-program pendidikan yang dilakukan sekolah harus benar-benar disampaikan kepada murid, terlebih dengan media daring tetap saja pihak sekolah harus benar-benar memperhatikan etika sebagai lembaga pendidikan. Penekanan belajar dirumah kepada murid harus benar-benar mendapat kawalan agar guru-guru yang mengajar melalui media garing tetap smooth dan cerdas dalam menyampaikan pelajaran-pelajaran yang wajib dipahami oleh murid.

\section{Kesimpulan}

Kebijakan belajar di rumah pada institusi pendidikan jelas menyebabkan gangguan besar, seperti pembelajaran siswa, gangguan dalam penilaian, pembatalan penilaian, peluang mendapatkan pekerjaan setelah lulus pendidikan, pembatalan penilaian publik untuk kualifikasi dalam seleksi pekerjaan. Bagaimana seharusnya pemerintah Indonesia melakukan yang terbaik untuk penanganan ini? Sekolah memerlukan sumber daya untuk membangun kembali kehilangan dalam pembelajaran, ketika mereka kembali membuka aktivitas pembelajaran. Rekoveri untuk pemulihan ini harus dilakukan secara cepat dan tepat dengan pengalokasian anggaran dari pemerintah untuk pendidikan. Pemangkasan birokrasi pendidikan harus segera dijalankan untuk menangani dampak Covid-19 ini bagi dunia pendidikan. Kebijakan penting yang harus dilakukan oleh menteri pendidikan adalah merekoveri penilaian untuk pembelajaran, bukan menghilangkan, disebabkan pentingnya faktor penilaian bagi siswa, sehingga kebijakan yang lebih baik adalah menunda penilaian bukan melewatkan penilaian internal sekolah. Bagi lulusan baru, kebijakan harus mendukung masuknya para lulusan (fresh graduet) ke pasar kerja untuk menghindari periode pengangguran yang lebih lama. Kementerian pendidikan harus berkoordinasi dengan menteri terkait agar lapangan kerja padat karya kembali dibuka dan disegarkan. 


\section{Referensi:}

Baharin, R., Halal, R., Aji, S., Yussof, I., \& Saukani, N. M. (2020). Impact of Human Resource Investment on Labor Productivity in Indonesia. Iranian Journal of Management Studies, 13(1), 139-164. https://doi.org/10.22059/ijms.2019.280284.673616

Bobonis, G. J., \& Morrow, P. M. (2014). Labor coercion and the accumulation of human capital. Journal of Development Economics, 108, 32-53. https://doi.org/10.1016/j.jdeveco.2014.01.004

Buana, Dana Riksa, "Analisis Perilaku Masyarakat Indonesia dalam Menghadapi Pandemi Virus Corona (Covid-19) dan Kiat Menjaga Kesejahteraan Jiwa," Salam: Jurnal Sosial dan Budaya Syar-i, Volume 7, No. 3 (2020).

Caroline Hodges Persell. (1979). Educations and Inequality, The Roots and Results of Strattification in America's Schools (Pertama). United States of America: The Free Press.

Carlsson, S and E Greaves (2013). Test Scores, Subjective Assesment, and Stereotyping of Ethnic Minorities. Journal of Labor Economics 31(3): 535-576

Carlsson, M, G B Dahl, B Ockert and D Rooth (2015). The Effect of Schooling on Cognitive Skills. Review of Economics and Statistics 97(3): 533-547

Jonsson, B., Waling, M., Olafsdottir, A. S., Lagström, H., Wergedahl, H., Olsson, C., ... Hörnell, A. (2017). The effect of schooling on basic cognition in selected nordic countries. Europe's Journal of Psychology, 13(4), 645-666. https://doi.org/10.5964/ejop.v13i4.1339

Lavy, V(2015). Do Differences in Schools, Instrution Time Explain International Achievement Gaps? Evidence from Developed and Developing Countries. Economics Journal 125.

Piopiunik, M, G Schwerdt, L Simon and L Woessman (2020). Skill, signals and employability: An experimental investigation. Europan Economic Review 123: 103374

Maggalatung, A.S.; Aji, A.M.; Yunus, N.R. How The Law Works, Jakarta: Jurisprudence Institute, 2014.

SyahAji, R. H., Yussof, I., Saukani, M. N. M., \& Baharin, R. (2020). Does education increase labor productivity? An evidence from Indonesia during reform era. Test Engineering and Management, 82(16193), 16193-16199.

Yunus, N.R.; Rezki, Annissa. "Kebijakan Pemberlakuan Lock Down Sebagai Antisipasi Penyebaran Corona Virus Covid-19," Salam: Jurnal Sosial dan Budaya Syar-i, Volume 7, No. 3 (2020).

Rohmah, S.N. "Adakah Peluang Bisnis di Tengah Kelesuan Perekonomian Akibat Pandemi Corona?," Adalah: Volume. 4, No. 1 (2020). 
Rizqon Halal Syah Aji

Rezki, Annissa; Anggraeni, RR. Dewi; Yunus, Nur Rohim. "Application of Civil Law Theory In the Termination of Custody of Adopted Children in Indonesia," Journal of Legal Research, Volume 1, No. 6 (2019). 


\section{Indexed by :}
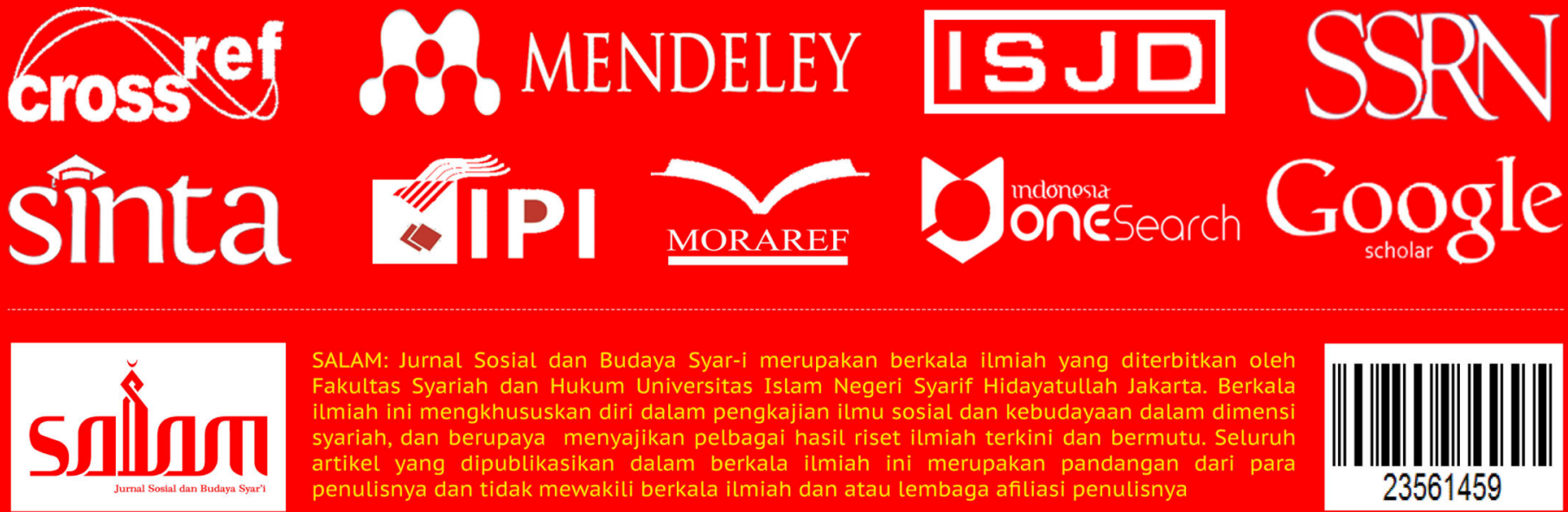

SALAM: Jurnal Sosial dan Budaya Syar-i merupakan berkala ilmiah yang diterbitkan oleh Fakultas Syariah dan Hukum Universitas Islam Negeri Syarif Hidayatullah Jakarta. Berkala ilmiah ini mengkhususkan diri dalam pengkajian ilmu sosial dan kebudayaan dalam dimensi syariah, dan berupaya menyajikan pelbagai hasil riset ilmiah terkini dan bermutu. Seluruh artikel yang dipublikasikan dalam berkala ilmiah ini merupakan pandangan dari para penulisnya dan tidak mewakili berkala ilmiah dan atau lembaga afiliasi penulisnya

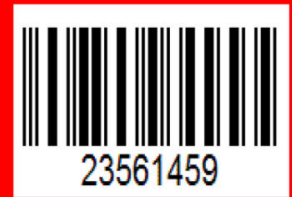

